$$
\text { 바이오-에너지/케미컬 동시-생산 시스템 바이오리파이너리의 동향 }
$$

김성호, 김길훈 ${ }^{\dagger}$

전문연구위원 KISTI ReSEAT, 대표이사 (주)수목에코 ${ }^{\dagger}$

(2013년 3월 20일 접수, 2013년 8월 20일 수정, 2013년 8월 20일 채택)

\title{
Trends of Biorefinery as Systems for Bioenergy/Biochemicals Co-Products
}

\author{
Seong Ho KIM, Kil-houn $\mathrm{KIM}^{\dagger}$ \\ KISTI ReSEAT Program, Su Mok ECO Co. Ltd $^{\dagger}$
}

(Received 20 March 2013, Revised 20 August 2013, Accepted 20 August 2013)

요 약

현대 사회에서 우리는 주로 화석 연료 인프라 위에 구축된 화석 연료 경제 시대에 살고 있다. 그 결과 발생하는 에너지 도전문제(예: 화석 연료의 자원 고갈 문제, 환경 오염 문제, 에너지 안보 문제)로 지속가능 발전은 한계에 부딪히고 있는 실정이다. 이들 도전문제를 극복하기 위해 기존 석유-기반 리파 이너리, 즉 석유 정제(ORF) 역할을 대체할 바이오에너지(예: 바이오연료, 전기, 열) 및 바이오케미컬 (예: C5 계열, C6 계열) 동시-생산 시스템으로 바이오매스를 사용한 바이오리파이너리(BRF) 개념이 새롭게 출현하였다. 이는 석유 경제에서 바이오경제로 패러다임 천이(shift)가 진행되고 있음을 가리키 는 지표(indicator)가 된다. 이러한 바이오매스-기반 경제는 현재 구축되어 있는 ORF 인프라를 거의 변경 없이 그대로 활용할 수 있는 높은 호환성, 적은 폐기물 발생량, 이산화탄소 중성적 친환경성, 지역 농업/임업 경제 활성화 등과 같은 매력적인 강점들을 갖고 있다. 무엇보다도 석유 자원 빈곤국이 고 석유 수입국이며 ORF 인프라를 이미 구축한 우리나라에서는 에너지 안보 및 지속가능 발전 측면에 서 고가치 BRF 시스템의 연구 개발 및 기술 사업화에 국가적 차원에서 아낌없이 투자와 지원을 제공해 야 할 필요성이 높아지고 있다. 이 연구에서는 바이오에너지/바이오케미컬 동시-생산용 시스템으로 활용될 BRF 기술의 국내외 동향을 소개하고자 한다.

주요어 : 바이오에너지, 바이오케미컬, 바이오리파이너리, 동시-생산

\begin{abstract}
In order to overcome the 21st century's challenges such as national energy supply security, global warming, and resource depletion, we are struggling to accelerate the paradigm shift in our life style from fossil fuel-based economy to biomass-based economy. In the context of sustainable bioeconomy revitalization, we comprehensively review the development status of the biorefinery as a system for bioenergy/biochemicals co-products on the basis of the various categories according to six criteria.
\end{abstract}

Key words : Bioenergy, Biochemicals, Biorefinery, Co-product.

\section{1. 서 론}

\section{1-1. 배경}

우리는 21세기 글로벌 메가트렌드(예: 웰빙, 지속 가능성)에 편승하면서 화석연료-기반 석유 경제에서

${ }^{\dagger}$ To whom corresponding should be addressed. 바이오매스-기반 바이오경제 패러다임으로 갈아타고 Tech Biz Consulting, INNOPOLIS Foundation Tel : 042-865-7073 E-mail : shghyym@naver.com 있는 중이다. 석유 경제에서 발생하는 이슈들(예: 에 
너지 안보 갈등, 환경 오염, 자원 고갈)을 해결하기 위한 방안의 하나로 지구촌 대부분의 나라들이 화석 연료 에너지원 대신에 재생가능 에너지원에 기반을 둔 수소 경제 패러다임으로 천이하는 연구 개발에 지 대한 관심을 가지고 활발한 국제적 R\&D SNS를 구 축하고 있다. 재생가능 에너지원 가운데 태양광, 풍 력, 해양 에너지(예: 조력), 바이오에너지 등이 주요 대체 에너지원으로 개발되고 있다. 이러한 맥락에서 오일 리파이너리(석유 정제; ORF; oil refinery)의 대 체 시스템으로 바이오리파이너리(바이오정제; $\mathrm{BRF}$; biorefinery) 시스템이 전세계적으로 구축되고 있다. $\mathrm{BRF}$ 는 우리 주변에 흔한 바이오매스에서부터 에너 지, 바이오케미컬, 바이오물질 등을 동시에 생산할 수 있다.

$\mathrm{EU}$ 에 따르면, 바이오기술(BT)은 적용 부문별로 색 상으로 표현하여 레드 $\mathrm{BT}$ (예: 보건 관련 기술), 그린 $\mathrm{BT}$ (예: 농업/임업 관련 기술), 화이트 $\mathrm{BT}$ (예: 산업용 $\mathrm{BT}$ )와 같이 세 가지 유형의 분야로 분류된다 [송효준 2005]. 화이트 BT 분야에서, 특히 바이오매스를 사용 한 바이오에너지 및 바이오화합물 동시-생산 시스템 은 기존 석유-기반 ORF 역할을 대체할 수 있는 바이 오매스-기반 BRF 개념으로 새롭게 출현하고 있다.

$\mathrm{EU}$ 회원국 및 북미 국가들은 BRF가 유발할 수 있 는 이산화탄소 배출량의 감축 및 지속가능 발전을 추 진력으로 삼아 BRF 기술의 개발에 국가 차원에서뿐 만 아니라 민간 부문에서도 전통 산업계(예: 제지/펄 프, 농식품)의 기업들이 $\mathrm{BRF}$ 상업화에 커다란 관심 을 두고 막대한 재원의 선점 투자를 진행하고 있다.

우리나라에서는 경유에 바이오디젤을 $2 \%$ 이상 의 무적으로 혼합하고 있는 실정이지만, BRF 기술은 아 직도 개발 초기 단계에 있다. 따라서 바이오산업의 이해관계자들이 다른 나라의 $\mathrm{BRF}$ 의 기술 현황을 파
악하고 우리나라 에너지 환경 실정에 맞는 BRF 기술 의 개발을 활발하게 할 수 있는 정보를 공유하여 $\mathrm{BRF}$ 기술 사업화에 보다 적극적으로 동참할 기회를 제공할 필요가 있다.

본 작업의 주요 목적은 우리나라가 바이오경제로 의 천이에 보다 능동적으로 대처할 수 있도록 $\mathrm{BRF}$ 동시-생산 시스템의 개념, 주요 시스템 유형, 주요 변 환 기술 등을 포함하면서 BRF 기술의 국내외 동향을 파악하고 더 나아가 향후 지속가능 성장의 추진력이 될 수 있는 바이오매스-기반 BRF 시스템의 도입 가 속화에 기여하려는 것이다.

\section{1-2. $\mathrm{ORF}$ 와 $\mathrm{BRF}$ 의 관계}

두 가지 개념 $\mathrm{ORF}$ 및 $\mathrm{BRF}$ 이 물질 흐름의 관점에 서 Fig.1에서 서로 대조되면서 잘 비교되어 있다 [문 혜선 201110].

화석 연료 경제에서 부터 바이오경제(즉, 바이오매 스-기반 경제)로의 천이(shift)도 표시되고 있다. 기존 산업은 $\mathrm{ORF}$ 산업을, 산업바이오는 BRF 개념을 의미 한다. ORF는 석유 경제의 기반을 이루면서 석유 연 료 및 석유-유래 화합물 등을 생산하는 반면에, $\mathrm{BRF}$ 는 바이오경제의 기반을 구성하고, 바이오연료 및 바 이오-유래 화합물(예: 고분자 화합물, 기능성 화학물 질) 등을 생산한다. 이러한 $\mathrm{BRF}$ 는 현재 구축되어 있 는 ORF 인프라를 거의 변경 없이 그대로 활용할 수 있는 높은 호환성, 적은 폐기물 발생량, 이산화탄소 중성적 친환경성, 농업/임업 경제 활성화 등과 같은 매력적인 강점들을 갖고 있다.

Landeweerd 등은 탄소 사이클 관점에서 $\mathrm{ORF}$ 개 념과 BRF 개념의 차이점을 비교하였다 [Landeweerd 201104]. 닫힌 시스템인 $\mathrm{BRF}$ 의 재생가능한 공급원 료(feedstock) 즉 바이오매스에 비해, 열린 시스템인

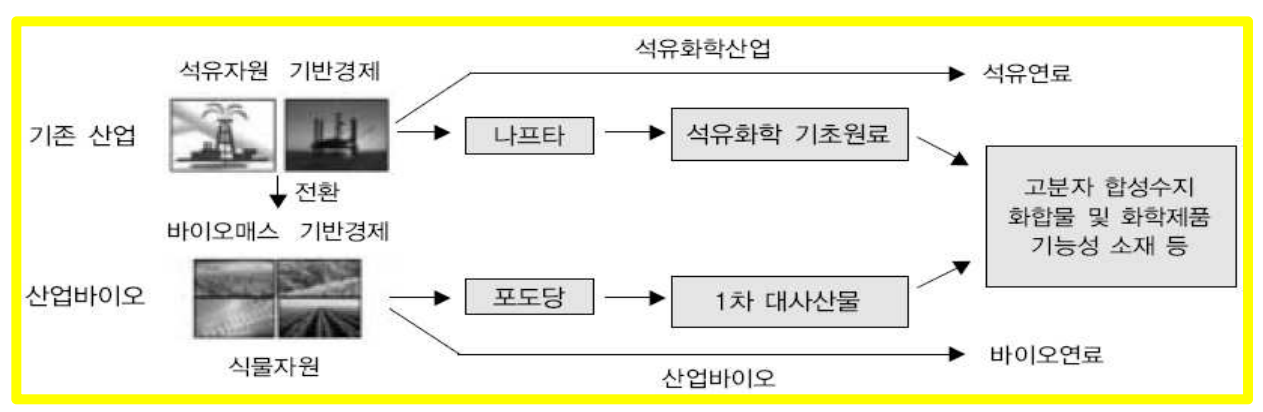

Fig. 1. ORF 및 $\mathrm{BRF}$ 비교 
$\mathrm{ORF}$ 의 재생불가능한 공급원료 즉 석유에는 자원의 고갈 문제가 내재되어 있다. 그 이유는 $\mathrm{BRF}$ 와 $\mathrm{ORF}$ 에서 필요로 하는 각각 수 년과 수백만 년의 자원 형 성 시간대의 커다란 차이로 인한 자원의 재생-불가능 성 때문이다.

$\mathrm{BRF}$ 산업이란 재생가능한 바이오매스(예: 동물, 식물, 미생물)를 공급원료로 사용하여 바이오연료, 바 이오화학소재 등을 동시적으로 생산하는 분야이고, 다음과 같은 환경성(예: 지구 온난화, 화석 연료 고갈) 및 경제성 관점에서 지속가능한 사회 구현을 위해 그 개발 중요성이 부각되고 있다 [문혜선 201110] [IEA 2011].

환경성과 관련하여, $\mathrm{ORF}$ 산업에서는 한정된 매장 량의 화석 연료에 바탕을 두고 있으며 환경 오염을 유발하지만, BRF 산업에서는 재생가능한 바이오매스 를 공급원료로 사용하므로 이산화탄소 배출량을 감축 시키고 지구 온난화 문제를 완화한다고 보는 견해가 있어 $\mathrm{BRF}$ 필요성이 커지고 있다. 경제성과 관련하여, $\mathrm{BRF}$ 산업은 기존 $\mathrm{ORF}$ 인프라에다가 $\mathrm{BRF}$ 관련 신 기술을 결합하여 화학 산업에 신성장 구동력을 제공 하고, 전방(upstream) 부문(예: 농업, 임업)부터 후방 (downstream) 부문(예: 자동차, 반도체, 의약품)까지 파급 효과를 미치고 있다. 따라서 국가 차원의 전략 적 산업으로 $\mathrm{BRF}$ 를 개발할 필요가 매우 크다.

다음으로 제2장 $\mathrm{BRF}$ 동시-생산 시스템에서는 1) $\mathrm{BRF}$ 개념의 정의, $\mathrm{BRF}$ 의 구성 요소 등을 포함하는 $\mathrm{BRF}$ 개념의 변천; 2) $\mathrm{BRF}$ 시스템의 유형(예: 개별 $\mathrm{BRF}$, 통합 $\mathrm{BRF}) ; 3) \mathrm{BRF}$ 에 적용되는 다양한 변환 기술(예: 열화학 변환, 바이오화학 변환) 등을 소개한 다. 제 3 장 국내외 기술 동향에서는 1) $\mathrm{EU}$ 회원국(예: 네덜란드, 독일) 및 유럽, 2) 북미 국가(예: 미국, 캐 나다), 3) 여타 국가(예: 일본), 4) 우리나라 등의 동 향을 살펴본다. 마지막으로 제4장 결론에서는 요약 및 향후 연구 개발 방향을 제시하고자 한다.

\section{2. $\mathrm{BRF}$ 동시-생산 시스템}

$\mathrm{BRF}$ 시스템의 개발 현황을 알아보기에 앞서 우선 $\mathrm{BRF}$ 시스템의 변천, 시스템 유형 등을 논의하고, 적 용되는 변환 기술을 소개하고자 한다. 다음에 BRF 시스템과 관련하여 나라별 개발 현황을 살펴보려고 한다.

\section{2-1. BRF의 변천}

일반적으로, 정제(refinery)란 특정 공급원료로부터 다양한 에너지, 연료, 생산품을 동시적으로 생산하는 개념, 공정, 플랜트, 시설, 또는 시설들의 클러스터 등 을 모두 가리킨다. 이러한 정제(예: ORF) 기술은 다 양한 공정들의 통합 시너지 및 규모 경제 등을 통해 에너지 절약을 극대화하기 위해 진화된 비용-효과적 인 동시-생산 기술이다 [Smith 200704]. 이러한 비용효과적인 전통 $\mathrm{ORF}$ 개념과 유사하게 $\mathrm{BRF}$ 개념이 형성됐다. 경제성 관점에서 볼 때, 이러한 $\mathrm{BRF}$ 의 경 쟁력은 저가치 고용량의 바이오연료 생산뿐만 아니라 고가치 저용량 바이오공생산품(biocoproducts)의 추 가적인 동시-생산에 근거를 두고 있다 [IEA 2011].

$\mathrm{BRF}$ 개념은 $\mathrm{BT}$ 분야에서 전혀 새로운 개념이 아 니다. 다양한 산업 부문(예: 설탕, 전분, 펄프/제지)에 서 전통 바이오연료 통합(integrated) 생산 시스템에 포함된 개념들이 BRF 시스템에 활용되고 있다 [IEA 2011]. 예컨대, 전통 바이오연료 통합 시스템에서도 투입물인 바이오매스(예: 농업 폐기물)는 생물학적 변 환(예: 혐기성 소화 또는 혐기성 분해)을 거쳐 바이오 가스와 비료를 생산하고, 이 바이오가스는 흡열반응 인 증기 변성 공정을 통해 에너지(예: 전기)와 합성가 스를 생산하며, 이 합성가스는 메탄올로 변환되어 바 이오디젤(예: FAME)과 글리세롤을 생산한다 [Bart 2010].

전통 바이오연료 통합 시스템을 좀 더 체계적으로 일반화시킨 BRF는 재생가능한 바이오매스로부터 에 너지, 연료, 가치성 화학제품 등을 동시에 생산하는 성장-지속가능한 총체적인 기술을 지칭하고 있다 [이 상엽 2010]. 예를 들면, 특정 BRF 시스템에서는 바 이오매스로부터 여러 가지 변환(예: 바이오화학 변환, 열화학 변환)을 통해 다양한 공-생산품, 즉 저용량 고 가치 생산품(예: 바이오화학물질) 및 고용량 저가치 생산품(예: 바이오연료)을 동시에 생산한다 [Bart 2010]. 일반적으로, BRF 시스템에서는 선행 공정(예: 전처리/추출/분리)을 거친 바이오매스를 변환 공정 (예: 열화학, 바이오화학)을 통해 다양한 산출물을 생 산한다. 선행 공정에서 생산되는 바이오생산품으로는 바이오물질(예; 파이버, 단백질) 및 식품, 사료 등이 있다 [Smith 200704]. 보통 가치성 화학물질은 BRF 조기 단계에서 바이오매스로부터 추출되고, 저가치 바이오연료를 위한 공급원료는 그 다음 단계에서 획 득된다. 
$\mathrm{BRF}$ 시스템은 전통 바이오연료 통합 시스템에 비 해 다음과 같은 특징을 갖는다 [IEA 2011]: 1) 바이 오매스 공급원료는 좀 더 다양하게 활용된다; 2) 자 원은 현행 바이오연료 생산 시스템에 비해 더 효율적 으로 활용된다; 3) 바이오매스를 다양하게 활용하는 경우에 일어나는 경쟁 심화가 줄어든다.

BRF-기반 바이오경제가 바탕에 깔고 있는 3 대 대 들보는 바이오생산품, 바이오에너지, 바이오연료 등 이다 [Kamm 200802]. 바이오경제 사슬은 바이오매 스, BRF, 3 대 대들보의 제조, 에너지 시장 등으로 연 결되어 있다. 특히, BRF-기반 바이오경제 실현 전략 은 두 가지로 볼 수 있다: 1) 중앙집권식 전략(예: 한 국); 2) 분산형 전략(예: 인도네시아). 중앙집권식 전 략에서는 기존의 ORF를 위한 인프라 및 시설에서 커 다란 변경 없이 $\mathrm{BRF}$ 로 용이하게 효과적인 진입이 가 능하다. 그러므로 ORF 기술이 발달한 우리나라에서 특히 BRF 동시-생산 시스템은 더욱 더 선호되고 있 는 지속가능 차세대 기술이다 [김 201209].

BRF 개념의 정의 : BRF 개념은 다음과 같이 다양 한 곳에서 유사하지만 상이하게 정의되고 있다: IEA(International Energy Agency; 국제에너지기구) 및 네덜란드 BIOPOL [IEA 2009], 바이오리파이너 리 Euroview [Soetaert 20090330], Soetaert, WEF(World Economy Forum; 세계경제포럼) [WEF 2010], Jungmeier [Jungmeier 201202].

결론적으로, 이들 개념을 바탕으로 우리는 $\mathrm{BRF}$ 를 다음과 같이 정의할 수 있다: $\mathrm{BRF}$ 란 투입물인 바이 오매스 자원(예: 오일, 전분, 당분, 리그노셀룰로즈)으 로부터 변환 공정(예: 바이오화학, 열화학, 물리화학, 기타) 기술 및 플랫폼(예: 6탄당 플랫폼, 리그닌 플랫 폼) 등을 통해 산출물인 바이오에너지(예: 바이오연 료, 전기, 열, 고체 연료) 및 바이오생산품(예: 화학물 질, 동물 사료, 식품, 바이오물질, 비료, 가스) 등을 지 속가능성 관점에서 동시에 생산하는 개념, 공정, 플랜 트, 시설, 또는 시설들의 클러스터 등을 의미한다. 엄 격한 정의에 따르면, $\mathrm{BRF}$ 는 적어도 하나의 에너지 산출물과 하나의 물질 산출물을 동시에 생산하여야 한다.

BRF 구성 요소 : 여기서는 $\mathrm{WEF}$ 의 3 대 요소 접근 법 [WEF 2010], IEA의 4대 요소 접근법 [IEA 2009] 등을 소개한다.
$\mathrm{WEF}$ 의 3 대 요소 접근법에서 $\mathrm{BRF}$ 는 다음과 같은 3 대 주요 요소를 가지고 파악될 수 있다: 1) 플랫폼 (platform); 2) 투입물인 공급원료; 3) 산출물. 3 대 요 소 접근법에서 플랫폼이란 공급원료와 산출물을 연결 하는 중간단계 변환 공정을 가리킨다. 예를 들어, 플 랫폼으로는 미생물 플랫폼, 열병합 발전(CHP; combined heat \& power) 플랫폼, 열화학 플랫폼, 바 이오화학 플랫폼 등이 사용되고 있다.

$\mathrm{IEA}$ 의 4대 요소 접근법에서 $\mathrm{BRF}$ 는 다음과 같은 4 대 주요 요소로 특징지어 질 수 있다: 1) 플랫폼; 2) 공급원료; 3) 산출물; 4) 변환 공정. 3 대 요소 접근법 과는 달리 4대 요소 접근법에서 플랫폼이란 공급원료 와 산출물을 연결하는 중간 단계 물질을 지칭한다. 예를 들면, $\mathrm{C} 5 / \mathrm{C} 6$ 당 플랫폼, 피롤리시스(pyrolysis; 열분해) 오일 플랫폼, 합성가스 플랫폼, 바이오가스 플랫폼, 리그닌 플랫폼 등이 사용되고 있다. 특정 $\mathrm{BRF}$ 시스템의 복잡도는 관여된 플랫폼 개수로 표시 될 수 있다.

공급원료는 농업 부문 에너지 작물(예: 전분계 작 물), 농업/임업/무역/산업 부문 바이오매스 잔여물(예: 짚), 동물 잔여물, 하수, $\mathrm{MSW}$ (지자체 고형 폐기물) 등에서 유래되고 있다 [Ahmed 2012]. 더 구체적으로 예를 들면, 목재, 농업 작물, 삼림 잔여물, 식물/동물유래 유기 잔여물, 수생 바이오매스(예: 조류, 해초 류), 산업 폐기물 등이 BRF 시스템에 투입되는 바이 오매스이다 [IEA 2011].

산출물로는 에너지 생산품(예: 바이오에탄올, 바이 오디젤, 바이오합성연료), 물질 생산품(예: 화학물질, 물질, 식품, 사료) 등이 있다. BRF에서 생산된 바이 오화학물질은 합성을 통해 다양한 분야(예: 산업 방 청용품, 합성섬유, 수송용/산업용 플라스틱, 안전한 식품 첨가물, 의약품, 미용용품)에 적용된다 [이상엽 2010].

일반적으로, 변환 공정은 다섯 가지로 분류될 수 있다: 1) 바이오화학 공정(예: 발효, 효소 변환); 2) 열 화학 공정(예: 가스화, 액체화, 피롤리시스); 3) 화학 공정(예: 산 가수분해, 합성, 에스테르화); 4) 기계적 공정(예: 프랙셔네이션(fractionation), 압착, 크기 감 축); 5) 하이브리드 공정.

BRF 유형의 명명법 : 앞에서 서술된 구성 요소에 따라 BRF 명명법 사례를 살펴보면 다음과 같다: 'C6 당 플랫폼 $\mathrm{BRF}$ (전분계 작물; 바이오에탄올, 동물 사 
료)'는 전분계 작물에서부터 바이오에탄올 및 동물 사료 생산을 위한 $\mathrm{C} 6$ 당 플랫폼 $\mathrm{BRF}$ 를 의미한다. ‘합성가스 플랫폼 $\mathrm{BRF}$ (짚; FT-디젤, 페놀)'는 짚에서 부터 FT-디젤 및 페놀 생산을 위한 합성가스 플랫폼 $\mathrm{BRF}$ 를 의미한다. 'C6\&C5 당, 합성가스 플랫폼 $\mathrm{BRF}$ (제재소 잔여물; 바이오에탄올, FT-디젤, 푸르푸 릴)'는 제재소 잔여물에서부터 바이오에탄올, FT-디 젤, 푸르푸랄 등의 생산을 위한 C6\&C5 당, 합성가스 플랫폼 $\mathrm{BRF}$ 를 의미한다.

\section{2-2. BRF 시스템 유형}

$\mathrm{BRF}$ 시스템의 유형은 크게 1) 투입물-기준 범주, 2) 산출물-기준 범주, 3) 기술-기준 범주, 4) 경로-기 준 범주, 5) 시설-기준 범주, 6) 결합-기준 범주 등으 로 나눠지고 있다.

첫째, 투입물-기준 범주에서는 BRF에 공급되는 투 입물인 바이오매스 자원에 초점을 두고 시스템의 유 형을 분류한다. 둘째, 산출물-기준 범주에서는 $\mathrm{BRF}$ 에 서 얻어지는 산출물인 생산품을 기준으로 시스템의 유형을 분류한다. 셋째, 기술-기준 범주에서는 BRF 생산 기술의 세대를 기준으로 시스템을 분류한다. 넷 째, 경로-기준 범주에서는 변환 경로를 기준으로 시 스템을 분류한다. 다섯째, 시설-기준 범주에서는 구축 된 시설의 군집화(clustering) 정도를 기준으로 시스 템 유형을 분류한다. 여섯째, 결합-기준 범주에서는 결합 정도를 기준으로 시스템 유형을 분류한다.

투입물-기준 : 현재까지 제안된 투입물-기준 범주 에 속한 유형의 $\mathrm{BRF}$ 시스템은 다음과 같이 다양하 다: 1) 전체 작물(whole crop) $\mathrm{BRF}$ 또는 시리얼
$\mathrm{BRF}$; 2) 그린 BRF; 3) 리그노셀룰로즈 BRF; 4) 삼 림 BRF; 5) 오일시드 BRF; 6) 폐유 BRF; 7) 폐기물 $\mathrm{BRF}$; 8) 미세조류 BRF 또는 해초 BRF; 9) 다단-플 랫폼 $\mathrm{BRF}$ (예: 2단-플랫폼 $\mathrm{BRF}$ ).

산출물-기준 : 산출물-기준 범주에서 BRF는 생산 중점을 에너지, 생산품, 또는 오일에 두는지에 따라 다음과 같은 유형들로 분류된다: 1) 바이오에너지-구 동 $\mathrm{BRF}$ (예: 바이오연료 플랜트); 2) 바이오생산품-구 동 $\mathrm{BRF} ; 3)$ 바이오오일-구동 $\mathrm{BRF}$.

기술-기준 : BRF는 생산 기술-기준 범주에서 다음 과 같이 네 가지 유형으로 분류된다 [Demirbas 2010]: 1) 제 1 세대 기술 유형; 2) 제 2 세대 기술 유형; 3) 제 3 세대 기술 유형; 4) 제4세대 기술 유형. 기술기준 유형이 Table 1에 정리되었다.

경로-기준 : $\mathrm{BRF}$ 는 변환 경로-기준 범주에서 다음 과 같이 다섯 가지 유형으로 분류된다: 1) 바이오합 성가스 BRF 유형; 2) 피롤리시스 BRF 유형; 3) 수열 -등급상승 BRF 유형; 4) 발효 BRF 유형; 5) 오일 플 랜트 $\mathrm{BRF}$ 유형. Table 2에 경로-기준 유형이 정리되 어 있다 [Demirbas 2010].

시설-기준 : 시설-기준 범주에서는 구축된 시설의 군집화 정도를 기준으로 시스템을 분류한다. $\mathrm{BRF}$ 는 시설-기준 범주에서 다음과 같이 두 가지 유형으로 분류된다: 1) 단일 유닛 유형; 2) 군집 시설 유형. 예 를 들어, 펼프/종이를 생산하면서 공정 잔여물로부터 전력을 생산하는 제지 공장은 단일 유닛 유형의 한 사례이다. 이는 부산물이나 인근 시설의 폐기물을 처

Table 1. 기술-기준 BRF 유형

\begin{tabular}{c|c|c}
\hline 유형 & $\begin{array}{c}\text { 공급원료 } \\
\text { 산출물 }\end{array}$ \\
\hline \hline 제1세대 BRF & $\begin{array}{c}\text { 식용 범주 : 당분계, 전분계, } \\
\text { 식물유, 동물 지방 }\end{array}$ & $\begin{array}{c}\text { 바이오알코올, 식물유, 바이오디젤, } \\
\text { 바이오합성가스, 바이오가스 }\end{array}$ \\
\hline 제2세대 BRF & $\begin{array}{c}\text { 비-식용 작물, 밀짚, 콘, 목재, 고체 폐기물, } \\
\text { 에너지 작물 }\end{array}$ & $\begin{array}{c}\text { 바이오알코올, 바이오오일, 바이오-DMF, } \\
\text { 바이오수소, 바이오FT디젤 }\end{array}$ \\
\hline 제3세대 BRF & 수생 범주: 조류 & 바이오디젤, 식물유, 제트 연료 \\
\hline 제4세대 BRF & 산출물 범주: 바이오디젤, 식물유 & 바이오가솔린 \\
\hline
\end{tabular}


Table 2. 경로-기준 BRF 유형

\begin{tabular}{l|l}
\hline \multicolumn{1}{c|}{ 유형 } & \multicolumn{1}{c}{ 산출물 } \\
\hline \hline 바이오합성가스 BRF & 합성가스, 수소, 메탄올, 디메틸 에테르, FT디젤 \\
\hline 피롤리시스 BRF & 바이오오일, 디젤 연료, 화학물질, 산소공급제(oxygenates), 수소 \\
\hline 수열-등급상승 BRF & $\mathrm{CxHx}$, 디젤 연료, 화학물질 \\
\hline 발효 BRF & 바이오에탄올 \\
\hline 오일-플랜트 BRF & 바이오디젤, 디젤 연료, 가솔린 \\
\hline
\end{tabular}

리하는 단일 유닛과 군집화를 통해 군집 시설 유형으 로 구축될 수 있다 [IEA 2011].

결합-기준 : 결합-기준 범주에서는 결합 정도를 기 준으로 시스템을 분류한다. BRF는 결합-기준 범주에 서 다음과 같이 두 가지 유형으로 분류된다: 1) 개별 $\mathrm{BRF}$ 유형; 2) 통합 BRF 유형. 통합 BRF 유형은 개 별 $\mathrm{BRF}$ 들을 연계시킨 것이다.

개별 BRF : 여기서는 앞에서 분류된 다양한 유형 의 개별 $\mathrm{BRF}$ 들 가운데 리그노셀룰로즈 $\mathrm{BRF}$ 를 소개 한다. 리그노셀룰로즈(lignocellulosic)는 목질/비목질 식물의 주요 구조 성분이며 셀룰로오스, 헤미셀룰로 오스, 리그닌 등으로 구성되어 있다. 리그노셀룰로즈 $\mathrm{BRF}$ 에서는 자연산-건조 바이오매스를 투입물로 사용 한다. 적합한 바이오매스로는 농업 잔여물(예: 밀 짚, 옥수수 대), 임업 잔여물(예: 통나무 잔여물, 바크), 펄프업/제지업과 같은 목재업의 잔여물(예: 종이-폐기 물, 블랙 리쿼), 셀룰로오스-함유 바이오매스/폐기물 (예: 잡초, 풀), 에너지 작물(예: 억새, 스위치 그래스) 등이 있다. 이들은 전처리 단계에서 셀룰로오스, 헤미 셀룰로오스, 리그닌 등과 같은 구성 성분으로 분리된 다음에 각각 처리된다. 리그노셀룰로즈 $\mathrm{BRF}$ 에서 생 산되는 고가치 바이오화학물질은 구성 성분별로 다음 과 같다 [Menon 201208].

첫째로, 셀룰로오스 성분에서 유도되는 화학물질로 는 폴리머, 레불린산(호박산, THF, MTHF, 1,4-부탄 디올, NMP, 락톤류), 에탄올, 젖산(아크릴산, 아세트 알데히드, 2,3-펜탄디온, 피루빈산), 이타콘산(3-메틸 THF, 3-메틸 피롤리돈, 2-메틸-1,4-부탄, 디아민, 이 타콘 디아미드), 3-hydroxypropanioc acid, 글루타민 산, 글루쿠론산, 호박산(2-피롤리돈, 1,4-부탄디올, THF) 등이 있다.

둘째로, 헤미셀루로오스 성분에서 유도되는 화학물
질로는 자일리톨, 에탄올, 부탄올, 수소, 2,3-부탄디올, 페룰산(예: 바닐린, 바닐린산, 프로토카테큐산), 젖산, 푸르푸릴, 키토산, 자일로올리고당 등이 있다.

마지막으로, 리그닌 성분에서 유도되는 화학물질로 는 합성가스, 합성가스 생산품(예: 메탄올/디메틸 에 테르, 에탄올, 혼합 액체 연료), 탄화수소(예: 시클로 헥산, 고 알킬레이트), 페놀(예: 크레졸, 유게놀, 코니 페롤, Syringols), 산화 제품(바닐린, 바닐산, DMSO, 알데히드, 퀴논, 방향족/지방족 산), 거대 분자(탄소 섬유, 활성 탄소, 폴리머 알로이, 고분자전해질, 대체 리그닌, 열경화성 수지, 합성물, 목재 방부제, 뉴트라 슈티컬(nutraceuticals)/약, 접착제, 송진) 등이 있다.

리그노셀룰로즈 $\mathrm{BRF}$ 는 케미컬/에너지 동시-생산 시스템에 속한다. 예를 들면, Reith가 제안한 에탄올기반 $\mathrm{C} 6$ 당 플랫폼 리그노셀룰로즈 $\mathrm{BRF}$ 에서, 셀룰로 오스계(C6 당분계)는 발효를 통해 에탄올과 에너지, 헤미셀룰로오스계(C5 당분계)는 화학 변환(예: 푸르 푸랄 합성)을 통해 푸르푸랄 화학물질, 리그닌계는 열화학 변환(예: 피롤리시스)을 통해 페놀 수지를 생 산한다 [Reith 201007]. Fig.2에 BIOPOL이 제안한 리그노셀룰로즈 BRF [Soetaert 20090330]의 공정 흐 름도가 나타나고 있다.

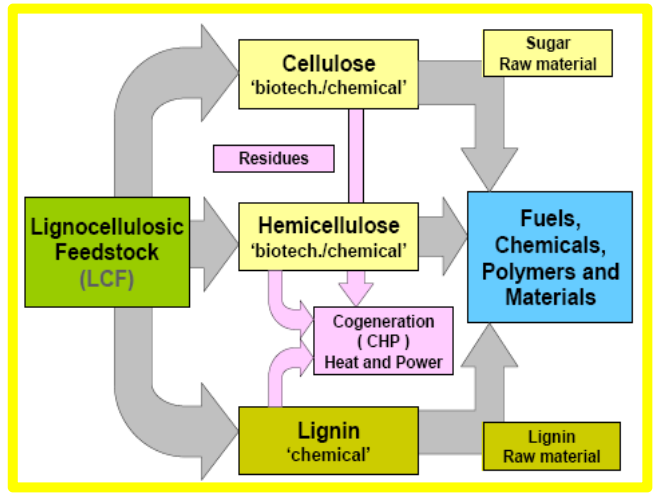

Fig. 2. 리그노셀룰로즈 $\mathrm{BRF}, \mathrm{BIOPOL}$ 
통합 BRF : 향후에는 규모 경제를 통한 경제성 향 상을 위해 상이한 유형의 개별 BRF가 투입물 단계에 서뿐만 아니라 처리 단계(예: 공정, 변환 기술)에서도 서로 통합되는 융복합화가 진행될 것이다. 예를 들면, 시리얼 $\mathrm{BRF}$ 는 짚과 같은 투입물도 처리하는 전체 작 물 BRF로 확장될 수 있다. 또한, 미래에는 인류의 먹 거리 자원 갈등을 해결하기 위해 식용 제 1 세대 대신 비식용 제 2 세대 바이오매스를 투입물로 사용하는 $\mathrm{BRF}$ 의 개발 및 사업화로 방향이 잡힐 것이다.

다양한 유형들의 개별 $\mathrm{BRF}$ 개념은 상호작용을 통 해 투입 단계, 처리 단계, 산출 단계 등에서 서로 연 계되고 있다. 그러므로 다양한 개별 $\mathrm{BRF}$ 들은 상승 효과를 얻기 위해 통합되어 한 개의 통합 BRF가 구 축될 수 있다. 예를 들면, 하나의 군집화 부지 내에서 개별 $\mathrm{BRF}$ 를 운영하는 참여 기업들 간의 연계를 통해 통합 $\mathrm{BRF}$ 를 구축하는 경우에, 참여 기업들은 생산 비용 절감, 생산 공정 효율 제고, 전략적 협력 진흥, 규모 경제의 이점 등을 달성할 수 있다. Soetaert이 소개한 통합 $\mathrm{BRF}$ 에서는 오일시드 $\mathrm{BRF}$, 그린 $\mathrm{BRF}$, 시리얼 $\mathrm{BRF}$, 리그노셀룰로즈 $\mathrm{BRF}$, 폐기물 $\mathrm{BRF}$ 등 이 통합되어 하나의 통합 BRF가 구축된다 [Soetaert 20090330]. 여기서는 다양한 공급원료의 투입 단계, 중간 플랫폼 단계, 산출물 단계 등이 상호 연계되어 하나의 통합 BRF가 구축되어 있다.

\section{2-3. $\mathrm{BRF}$ 변환 기술}

$\mathrm{BRF}$ 시스템에서 변환 공정은 단순하게 열화학 변 환 공정, 바이오화학 변환 공정 등으로 분류된다. 더 상세하게 분류하면, 열화학 변환 공정에는 피롤리시 스(pyrolysis) 기술, 액체화(liquefaction) 기술, 가스화 기술 등이 속하고, 바이오화학 변환 공정에는 발효 기술, 혐오성 소화 등이 속한다. 피롤리시스에서는 산
소 없는 조건에서 바이오매스를 가열하여 피롤리시스 오일을, 가스화에서는 바이오매스를 가열하여 일산화 탄소와 수소의 혼합 기체를 생산한다 [NREL 200901].

\section{3. 국내외 기술 동향}

우리나라 BRF 산업은 미국 및 유럽 국가에 비해 기술성 측면, 시장성 측면에서 초기 단계에 있으며 특정 분야(예: 발효 기술)를 제외한 여타 분야에서 기 술 수준도 낮은 편이다. 반면에, 우리나라가 이미 석 유화학 산업에서 구축한 시장, 기술, 생산력 등은 향 후에 우리나라 BRF 산업에 긍정적 요인으로 작용할 수 있다 [문혜선 201110].

유럽에서 파일럿 $\mathrm{BRF}$ 시설, 실증 $\mathrm{BRF}$ 시설 등이 운전 중에 있거나 건설 중에 있고, 특정 $\mathrm{BRF}$ 시설은 상업 운전 중에 있다. Table 3 에 현재 서구에서 운전 중인 리그노셀룰로즈계 공급원료 $\mathrm{BRF}$ 의 파일럿 플 랜트들이 정리되어 있다 [Fagernas 20090330]. 여기 서 $\mathrm{BRF}$ 유형은 앞에서 논의된 명명법에 따라 표기되 었다.

여기서는 국외 기술 동향과 관련하여, $\mathrm{EU}$ 회원국 (예: 네덜란드, 덴마크, 독일, 오스트리아, 프랑스, 영 국, 이태리), 노르웨이, 북미(예: 미국, 캐나다), 일본, 우리나라 등의 BRF 개발 현황을 국가별로 소개하고 자 한다.

네덜란드 : 현행 $\mathrm{BRF}$ 파일럿 및 실증 시설들로는 Core Bio-MCN/Biorefinery Cluster, Cargill/ Nedalco(Sas van Gent 위치), Greenmills(암스테르담 항 소재), ECN MILENA \& PATRIG 파일럿 시설 등이 있다 [IEA 2009]. 이 가운데 특히 Greenmills

Table 3. 현행 BRF 파일럿 플랜트

\begin{tabular}{l|l}
\hline \multicolumn{1}{c|}{ BRF 유형 } & \multicolumn{1}{c}{ 국가별 파일럿 플랜트 } \\
\hline \hline 합성가스 플렛폼 BRF(삼림 잔여물; FT-디젤) & 핀란드 StoraEnso, 독일 Choren, 미국 UPM \\
\hline 합성가스 플랫폼 BRF(블랙 리쿼; FT-디젤, DME) & 스웨덴 Chemrec \\
\hline 바이오에탄올 플랫폼 BRF(목재; 바이오에탄올) & 스웨덴 SEKAB \\
\hline 바이오에탄올 플랫폼 $\mathrm{BRF(톨유;} \mathrm{바이오에탄올)}$ & 스웨덴 Sunpine \\
\hline 바이오에탄올 플랫폼 BRF(짚; 바이오에탄올) & 스페인 Abengoa, 덴마크 Dong Energy \\
\hline 플랫폼 BRF(짚; FT-디젤) & 독일 FZK \\
\hline 플랫폼 BRF(짚; 셀룰로오스 펄프) & 프랑스 CIMV \\
\hline
\end{tabular}


실증 시설은 $\mathrm{C} 6 / \mathrm{C} 5$ 당 플랫폼 $\mathrm{BRF}$ 에너지/케미컬 동시-생산 시스템이다.

Greenmills 실증 시설은 투입물(예: 사용후 식물성 오일, 그리스, 기타 생분해성 유기 잔여물)에서 산출 물(예: 바이오디젤, 에탄올, 바이오가스, 전력, 열)을 생산하는 $\mathrm{C} 6 / \mathrm{C} 5$ 당 플랫폼 $\mathrm{BRF}$ 에너지/케미컬 동시생산 시스템이다. 연간 생산량은 바이오디젤 2억 리 터, 전력 1,000 만 $\mathrm{We}$, 바이오가스 2,500 만 $\mathrm{m} 3$ 등에 달한다.

네덜란드에서 운전 중인 기존 상업용 $\mathrm{BRF}$ 시설들 로는 Bio MCN, Vierhouten Vet, Ecoson/Vion, BioValue, Ten Kate Vetten, Food industry 등이 있 다 [IEA 200909]. 특히, Ecoson/Vion 시설은 투입물 (예: 폐육 산업)에서 산출물(예: 바이오가스, CHP, 바 이오디젤)을 생산하는 $\mathrm{BRF}$ 에너지/연료 동시-생산 시스템이다.

덴마크 : 현행 $\mathrm{BRF}$ 파일럿 및 실증 시설들로는 2004년부터 운전 중인 Inbicon 파일럿 시설 및 실증 시설, 2009년 9월부터 운전 중인 Maxiflex 파일럿 시 설 등이 있다. 특히, Inbicon 파일럿 시설은 바이오화 학적 변환을 통해 투입물(예: 리그노셀룰로즈 잔여물) 에서 산출물(예: 바이오에탄올, 사료, 열, 전력)을 생 산하는 $\mathrm{C} 6 / \mathrm{C} 5$ 당 및 리그닌 플랫폼 $\mathrm{BRF}$ 에너지/케 미컬 동시-생산 시스템이다.

예를 들어, Inbicon 파일럿2 시설은 리그노셀룰로 즈 잔여물(짚)에서부터 리그닌계 플랫폼, $\mathrm{C} 5 / \mathrm{C} 6$ 당분 계 플랫폼 등을 사용한다. 리그닌계 플랫폼에서부터 연소 공정을 통해 에너지(예: 전기, 열)를, C6 당분계 플랫폼에서부터 분리/증류를 통해 바이오연료(예: 바 이오에탄올)를, C5 당분계 플랫폼에서부터 바이오생 산품(예: 동물 사료)을 생산한다 [IEA 2009].

덴마크에서 현행되고 있는 상업용 BRF 시설들로 는 Agroferm, Dangront, Daka Biodiesel 등이 있다.

독일 : 현행 $\mathrm{BRF}$ 파일럿 및 실증 시설들로는 CHOREN Industries GmbH사(Freiberg 위치), Green Biorefinery Havelland, Emsland-Starke $\mathrm{GmbH}$ 사 (Wietzendorf 위치) 등이 있다. 이 가운데 특히 Emsland-Starke $\mathrm{GmbH}$ 사 실증 시설은 $\mathrm{BRF}$ 에너지/ 생산품 동시-생산 시스템이다.

독일 현행 상업용 BRF 시설들로는 Südzucker, Emsland-Stärke $\mathrm{GmbH}$ (Wietzendorf 위치), Biowert,
CropEnergies, Zellstoff Stendal 등이 있다. 특히, Zellstoff Stendal 시설은 투입물(예: 목재)에서 산출 물(예: 바이오생산품, 바이오에너지)을 생산하는 BRF 에너지/생산품 동시-생산 시스템이다. 더 상세하게 말 하면, Emsland-Stärke $\mathrm{GmbH}$ 시설은 투입물(예: 총 체 작물)에서 산출물(예: 바이오생산품, 바이오에너 지)을 생산하는 총체 작물 에너지/생산품 동시-생산 시스템이다. 독일 Zellstoff Stendal 사는 리그노셀룰 로즈계 작물을 투입하여 리그닌 플랫폼에서부터 연소 공정을 통해 바이오에너지(예: 전기, 열)를, 제지 공정 을 통해 바이오물질(예; 종이)을 생산한다.

오스트리아 : 현행 BRF 실증 시설로 Green Biorefinery Upper Austria 이 있다. 이 실증 시설은 $\mathrm{BRF}$ 에너지/생산품 동시-생산 시스템이다. 더 상세 하게 말하면, Green Biorefinery 실증용 시설은 리그 노셀룰로즈계 작물을 투입하여 C6 당 플랫폼에서부 터 발효 공정을 통해 바이오연료(예: 바이오에탄올) 를, 연소 공정을 통해 바이오에너지(예: 전기, 열)를, 제지 공정을 통해 바이오물질(예: 종이)을 생산한다.

현행 BRF 상업용 시설들로는 Lenzig AG 시설, Danisco 시설 등이 있다. 이 가운데 특히 Lenzig AG 시설은 투입물(예: 섬유, 펄프)에서 산출물(예: 바이오 화학물질, 바이오에너지)을 생산하는 C5 당 플랫폼 및 리그닌 플랫폼으로 구성된 $\mathrm{BRF}$ 에너지/케미컬 동 시-생산 시스템이다. 예를 들어, 오스트리아 Lenzig $\mathrm{AG}$ 상업용 시설은 리그노셀룰로즈계 작물을 투입하 여 펄프 밀 고정을 거쳐 C5 당 플랫폼에서부터 화학 반응을 통해 바이오화학물질(예: 푸르푸랄) 및 식품 (예: 자일로즈)을, 리그닌 플랫폼에서부터 연소 공정 을 통해 바이오에너지(예: 전기, 열)를, 파이버 생산 공정을 통해 바이오물질(예: 파이버)을 생산한다.

프랑스 : 현행 BRF 파일럿 및 실증 시설들로는 SICA Atlantique 실증 플랜트, Solvay 실증 플랜트, BioAmber (ARD-DNP) 실증 플랜트, Futurol (Procethol 2G) 연구/파일럿 플랜트 등이 있다.

현행 $\mathrm{BRF}$ 상업용 시설들로는 $\mathrm{ARD} /$ Cristal Union/Chamtor, Tembec/Smurfit, DRT, Novance, Roquette 등이 있다. 이 가운데 특히 $\mathrm{ARD} /$ Cristal Union/Chamtor 시설은 BRF 에너지/케미컬 동시-생 산 시스템이다. 예를 들어, 프랑스 Roquette 상업용 시설은 전분계 작물(예: 밀, 메이즈, 감자, 피즈, 미세 
조류)을 투입하여 가수분해 공정을 거쳐 C6 당 플랫 폼에서부터 발효를 통해 유기산 그리고 수소화를 통 해 바이오화학물질(예: 소르비톨, 폴리올)을, 건조 공 정 및 화학 공정을 거쳐 식품(예: 전분)을, 부산물로 동물 사료를 생산한다.

영국 : BRF 개발과 관련하여, Seal Sands에 소재 하고 있는 Ineos Bio사에서 상업용 규모로 폐기물 $\mathrm{BRF}$ 시설을 2012년부터 Teesside에서 가동할 예정 이다. 이 $\mathrm{BRF}$ 는 바이오폐기물에서 가스화 공정을 통 해 산출물(예: 바이오에탄올, 전기, 열)을 생산한다 [Tomkinson 201109]. 여기서는 폐기물에서 액체 바 이오연료(즉, 바이오에탄올)를 생산하는 가스화 공정 이 나타난다. 이 시설의 예상 생산량이 Table 4에 정 리되어 있다.

이태리 : 국립 신기술 에너지 경제 지속 공사 (ENEA; National Agency For New Technologies Energy and Economic Sustainable Development)에 서는 리그노셀룰로즈 잔여물에서 열화학 변환 공정을 통해 산출물(예: 에너지, 연료, 화학물질)을 생산하는 연구용 BRF 시설을 가동하고 있다 [deBari 2012]. 이 시설은 ‘합성가스 플랫폼 $\mathrm{BRF}$ (리그노 잔여물; 합 성 바이오연료, 화학물질, 전기, 열)'이다.

바이오플라스틱 제조사인 Novamont 사에서는 이 태리 Terni 부지에 그린 $\mathrm{BRF}$ 시설 $\mathrm{E} 35 \mathrm{~m}$ 을 가동하고 있다(http://www.novamont.com/). 이 BRF 시설은 투 입물(예: 식물유, maize 전분)에서 산출물(예: 화학물 질, 물질, 에너지)을 생산하고 있다 [Mastroianni 201110]. 이는 '그린 BRF(식물유, maize 전분; 화학 물질, 물질; 에너지)' 이다. 여기서 산출된 물질은 생 분해 폴리에스터(Origi-Bi) 및 전분-기반 열 플라스틱 (Mater-Bi) 등을 제조할 때에 쓰인다.
노르웨이 : 보레가르트사(www.borregaard.com)는 현재 Sarpsborg에 소재한 보레가르트(Borregaard) $\mathrm{BRF}$ 시설을 가동 중이다. 이 시설에서는 리그노셀룰 로즈(목질계; lignocellulosic) 바이오매스를 바이오화 학물질(예: 셀룰로오스, 리그닌, 바닐린)과 바이오연 료(예: 에탄올)로 변환하고 있다 [Rodsrud 2012].

미국 : EERE에 따르면, BRF 기술 개발은 다음과 같은 세 가지 범주로 구별되어 단계적으로 수행되고 있다 [EERE 201207]: 1) 파일럿 규모, 2) 실증용 규 모, 3) 상업용 규모.

첫째로, 파일럿 규모 범주에서는 선별된 유망 기술 들의 타당성을 평가하기 위해 건조 기준 최소 1 톤/일 처리량을 포함한다. 둘째로, 실증용 규모 범주에서는 파일럿 규모에서 타당성이 검증된 기술들의 규모 확 장성(scale-up)을 평가하기 위해 건조 기준 최소 50 톤 /일 처리량, 즉 상업용 규모의 $1 / 50 ~ 1 / 10$ 처리량을 목 표로 한다. 마지막으로, 상업용 규모 범주에서는 비용 -효과적으로 산출물(예: 바이오연료, 바이오전기, 바 이오생산품)을 생산하기 위해 건조 기준 최소 700 톤/ 일 처리량을 수반한다.

2012년 7월 현재, 미국에서는 미국경기부양법 (ARRA; American Recovery and Reinvestment Act) 에 의해 조성된 기금 투자로 12 개 $\mathrm{BRF}$ 파일럿 시설 프로젝트, 5 개 $\mathrm{BRF}$ 실증 시설 프로젝트 등을 진행하 고 있다. 상업용으로는 누적 생산 용량 1 억 갈론/년에 달하는 5 개 상업용 통합 $\mathrm{BRF}$ 가 건설되고 있다. 다섯 개 가운데 네 개는 미국 에너지부(US DOE) 및 산업 계의 공동 부담 비용으로, 한 개는 ARRA 기금으로 진행되고 있다.

캐나다 : 현재 $\mathrm{BRF}$ 시설 부지는 주로 펄프/제지 시설, 농식품 시설 등의 부지와 함께 하고 있다. 현행

Table 4. 영국 Ineos Bio BRF의 생산량 예상치

\begin{tabular}{c|c|c|c|c|c}
\hline & $\begin{array}{c}\text { 에탄올 } \\
(\mathrm{kt} / \mathrm{y})\end{array}$ & $\begin{array}{c}\text { 전체 전기 Power } \\
(\mathrm{MW})\end{array}$ & $\begin{array}{c}\text { 매도 전기 } \\
(\mathrm{MW})\end{array}$ & $\begin{array}{c}\text { 공급원료 필요량 } \\
(\mathrm{kt} / \mathrm{y})\end{array}$ & 가동 예정 \\
\hline \hline 단일 Phase A & 24 & 7 & 3 & 124 & 2012 \\
\hline 단일 Phase B & 120 & 36 & 20 & 621 & 2015 \\
\hline 통합 BRF 시설 & 144 & 43 & 23 & 745 & \\
\hline
\end{tabular}


$\mathrm{BRF}$ 파일럿 및 실증 시설들로는 Lignol Innovations Corporation 파일럿 시설, plantEnerkem Westbury 산업용 실증 시설, Enerkem Sherbrooke 파일럿 및 연구 시설, 오타와 소재 Iogen Corporation 실증 시 설, Syntec Biofuels Inc. 등이 있다. 이 가운데 특히 Iogen Corporation 실증 시설은 $\mathrm{C6} / \mathrm{C} 5$ 당 및 리그닌 플랫폼 $\mathrm{BRF}$ 에너지/케미컬 동시-생산 시스템이다.

현행 BRF 상업용 시설들로는 Ensyn, Tembec, Dynamotive, Nexterra/Tolko 등이 있다. 예를 들어, Ensyn 상업용 시설은 '피롤리시스 액체 플랫폼 $\mathrm{BRF}$ (목재; 합성 바이오연료, 수지, 전분가루, 전기, 열)'이 다. 더 상세하게 설명하면, 이 시설에서는 리그노셀룰 로즈계 잔여물(목재)을 투입하여 피롤리시스 변환을 거쳐 피롤리시스 액체 플랫폼에서부터 수소화/등급상 승 공정을 통해 합성 바이오연료를, 분리/프랙션에이 션 공정을 통해 폴리머(예: 수지)를, 화학반응에서부 터 식품(예: 전분가루)을, 연소 공정을 통해 합성 바 이오에너지(예: 전기, 열)를 생산한다.

일본 : Saka는 폐기물 바이오매스(예: 폐유, 폐목 재, 폐종이, 하수찌꺼기, 음식 폐기물)에서 초임계 유 체 기술을 통해 산출물(예: 바이오연료, 바이오화학물 질, 바이오물질, 에너지)을 생산하는 폐기물 $\mathrm{BRF}$ 에 너지/생산품 동시-생산 시스템을 제안하였다 [Saka 200912].

우리나라 : 우리나라는 아직까지 BRF 기술의 초기 단계에 놓여 있다. $\mathrm{BRF}$ 는 제품 제조 단계에서 기존 $\mathrm{ORF}$ 와 동일한 플랫폼을 활용하고 있다. 그러므로 $\mathrm{BRF}$ 기술을 개발하여 이미 구축되어 있는 $\mathrm{ORF}$ 의 현행 생산 인프라와 결합한다면, 새롭게 부상하는 $\mathrm{BRF}$ 분야에서도 경쟁력을 가질 수 있다 [문혜선 201110]. BRF 기술에서는 미생물 이용 변환 기술에 서 연구개발이 수행되고 있다. 미생물 이용 변환 기 술에서는 특정 $\mathrm{BRF}$ 에 적합한 균주 개발이 중요하다. 특히, 최근 KAIST 연구팀은 대사 공학 및 시스템생 물 공학에 바탕을 둔 균주 개발에 초점을 두고 있다 [이상엽 2010].

\section{4. 결론}

이 연구에서는 바이오에너지/바이오케미컬 동시-생 산용 시스템으로 활용될 BRF 기술의 국내외 동향을
소개하였다. 무엇보다도 석유 자원 빈곤국이고 석유 수입국이며 ORF 인프라를 구축하고 있는 우리나라 에서는 에너지 안보 및 지속가능성 측면에서 BRF 시 스템의 연구 개발 및 기술 사업화에 국가적 차원에서 아낌없이 투자와 지원을 제공해야 할 필요성이 높아 지고 있다. BRF 기술의 개발 현황을 살펴본 결과, 우 리나라는 BRF 기술 수준 및 시장 형성에서 아직 초 기 단계에 있지만 향후에는 글로벌 BRF 시장을 선도 하기 위해 바깥으로는 이러한 국제적 활동에 동참하 고, 안으로는 우리나라 ORF 산업계가 이미 구축하고 있는 인프라(예: 시장, 기술, 생산력)를 활용한 BRF 연구 개발에 과감한 재정적 투자와 정책적 지원을 도 모하여야 할 것이다.

무엇보다도 우리나라에 구축되어 있는 기존 ORF 인프라를 살린 $\mathrm{BRF}$ 의 중앙집권적 확산 전략이 매우 비용-효과적이고 대규모 제조에 적합한 것으로 파악 되었다. 향후에는 BRF 관련 신규 기술/시스템 개발 에서 먼저 파일럿 플랜트를 건설하여 단계적으로 운 영 경험과 노하우 등을 축적하여야 하고, 다음에 상 업용 규모 제조를 위해 저렴하고 풍부한 바이오매스 공급원료의 공급원 다변화 및 확보 개발이 필요하다.

\section{감사의 글}

이 연구는 한국과학기술정보연구원(KISTI)이 교육 과학기술부 과학기술진흥기금과 복권기금으로 수행 하는 「2012 ReSEAT 프로그램」지원에 의해 일부 분 수행되었습니다.

\section{참고문헌}

1. [송효준 2005] 송효준 (2005): 화학산업 혁신 이끄 는 산업바이오테크놀로지. LG경제연구원, 2005.

2. [문혜선 201110] 문혜선 (201110): 바이오화학 산 업의 현황과 과제. 산업연구원, 2011년 10월.

3. [Landeweerd 201104] Landeweerd L et al. (201104): From petrochemistry to biotech: a European perspective on the bio-based economy. Interface Focus, Apr 6, 2011(1), pp.189-195.

4. [IEA 2011] IEA (2011): Technology Roadmap Biofuels for Transport. IEA, 2011.

5. [Smith 200704] Smith W (200704): Ch.8 Biorefinery, in Literature review: State of the art 
in biorefinery development. NFC 07_008, Tamutech Consultancy, A report prepared for the National Non-Food Crops Centre(NNFCC), Apr 2007.

6. [Bart 2010] Bart JCJ, Palmeri N, and Cavallaro S (2010): Biodiesel Science and Technology: From Soil To Oil. CRC Press, 2010.

7. [이상엽 2010] 이상엽, 장유신 (2010): 바이오리파 이너리 기술의 현재와 향후 전망. Bioin 스페셜 Zine, 2010년 15호, 2010.

8. [Kamm 200802] Kamm B (200802): Definition and technical status of biorefineries. Presented at the BioreFuture2008, 12 Feb 2008, Brussels.

9. [김 201209] 김성호 (201209): 바이오정제에 의한 화학물질/에너지 동시 생산 시스템. 기술보고서 SYS-TR-201209-1, (주)시스테미아지앤이, 대전, 2012년 9월 16일.

10. [IEA 2009] IEA (2009): IEA Bioenergy Task 42 Biorefinery. IEA, Brochure, 2009.

11. [Soetaert 20090330] Soetaert W (20090330): Defining biorefineries and different concepts. Presented at the BioreFuture2009, 30 Mar 2009, Brussels.

12. [WEF 2010] WEF (2010): The future of industrial biorefineries. World Economic Forum, Geneva, Switzerland.

13. [Jungmeier 201202] Jungmeier G (2012): Innovative Biofuel-driven Biorefinery Concepts and their Assessment? An outlook until 2025 in IEA Bioenergy Task 42 "Biorefinery. Presented at the Biorefinery Conference 2012: Advanced Biofuels in a Biorefinery Approach, Feb 28 Mar 1, 2012, Copenhagen, Denmark.

14. [Ahmed 2012] Ahmed MM (2012): BIOMASS AS A RENEWABLE SOURCE OF CHEMICALS FOR INDUSTRIAL APPLICATIONS. International Journal of Engineering Science and Technology (IJEST), 2012.

15. [Demirbas 2010] Demirbas A and Demirbas MF (2010): Ch7. Biorefineries, in Algae energy Algae as a new source of biodiesel. Springer, 2010 .
16. [Menon 201208] Menon V and Rao M (201208): Trends in bioconversion of lignocellulose: Biofuels, platform chemicals \& biorefinery concept. Progress in Energy and Combustion Science 38(4), Aug 2012, pp.522-550.

17. [Reith 201007] Reith $\mathrm{H}$ et al. (201007): Development of lignocellulose biorefinery for co-production of chemicals, fuels, electricity and heat: Overview \& results of the IP BIOSYNERGY (FP6). Presented at the Meeting on Biorefineries \& Bio-based Products, Amsterdam(NL), Mar 2010, or ECN-L--10-07215, Jul 2010.

18. [NREL 200901] NREL (200901): Thermochemical Process Development Unit: Researching Fuels from Biomass. Report No. BR-510-44034, NREL, 4pp, January 2009.

19. [Fagernas 20090330] Fagernas L and Solantausta Y (200903): Lignocellulosic Biorefinery. Presented at the BioreFuture2009, Mar 30, 2009, Brussels.

20. [IEA 200909] IEA (200909): Biorefineries: Adding value to the sustainable utilisation of biomass. International Energy Agency (IEA), Task 42 Booklet, Sep 2009.

21. [Tomkinson 201109] Tomkinson J (201109): Sustainable Chemicals and Materials from Plant Sources. Presented at the UK's National Centre for Biorenewable Energy, Fuels and Materials, Sep 2011.

22. [deBari 2012] de Bari I (2012): Current status of biorefineries in Italy - R\&D activities. Presented at the Biorefinery Conference 2012: Advanced Biofuels in a Biorefinery Approach, Feb 28-Mar 1, 2012, Copenhagen, Denmark.

23. [Mastroianni 201110] Mastroianni F (201110): Novamont, its integrated biorefinery model and the development of a system-based economy. Presented at the "Europe for sustainable plastics" Launch Conference of the PLASTiCE Project, Bologna, 25th Oct 2011.

24. [Rodsrud 2012] Rodsrud G et al. (2012): 
History and future of world's most advanced biorefinery in operation. Biomass and Bioenergy 46, 46-59, 2012.

25. [EERE 201207] EERE (201207): Integrated Biorefineries: Biofuels, Biopower, and Bioproducts. DOE/EE-0767, EERE, USDOE, Jul 2012.

26. [Saka 200912] Saka S (200912): 3.2 Recent Progress in Biorefineries in Japan as Introduced by Supercritical Fluid Science and Technology, pp.71-77, in Biorefinery-based Knowledge Import from outside the EC. BIOREF-INTEG, Final Deliverables D3total, D6.3.1 and D6.6, Dec 2009. 